\title{
Absolute Freedom of Mind and Regulating Actions: Tendency of Case Law in the Supreme Court of Japan
}

Hitoshi Miyahara

Faculty of Law, Toyo University

Follow this and additional works at: https://gensoken.toyo.ac.jp/japanese-society-and-culture

Part of the Constitutional Law Commons, and the Courts Commons

\section{Recommended Citation}

Miyahara, Hitoshi (2019) "Absolute Freedom of Mind and Regulating Actions: Tendency of Case Law in the Supreme Court of Japan," Japanese Society and Culture: Vol. 1 , Article 1.

DOI: $10.52882 / 2434-1738$

Available at: https://gensoken.toyo.ac.jp/japanese-society-and-culture/vol1/iss1/1

This Article is brought to you for free and open access by Institute of Social Sciences. It has been accepted for inclusion in Japanese Society and Culture by an authorized editor of Institute of Social Sciences. 


\title{
Absolute Freedom of Mind and Regulating Actions: Tendency of Case Law in the Supreme Court of Japan
}

\author{
Hitoshi Miyahara*
}

\begin{abstract}
We have absolute protection for our internal beliefs, but this never means the same protection for our external actions. So we have to decide which external actions are permitted, bearing in mind internal protection. Therefore, I introduce some cases of the Supreme Court of Japan (coercing apology, playing the piano accompaniment to Kimigayo, membership fee, Incantation to a mental patient based on religious belief, dissolving the religious corporation, absent from class on fathers' visiting day and the Kendo lesson) that analyzed the relationship between thoughts and actions.
\end{abstract}

Key words: Freedom of mind, freedom of religion, relationship of thought and action, Kimigayo, membership fee

\section{Introduction}

Article 19 of the Constitution of Japan protects freedom of mind, and we understand that this protection is absolute because we can never enjoy individual dignity without it (1). But Article 19 does not mean that an action emanating from or ordered by our minds or convictions is protected absolutely. For example, we are permitted to think that all human beings should be destroyed, but we are prohibited from making a start on such an action ${ }^{(2)}$ Articles 39 and 40 of the Anti-Subversive Activities Law prohibit inciting a mob to set fire to houses in which someone lives. They should punish perceptible, objective actions, but not thoughts on which actions were based (44 (6) KEI • SHU 463 (1990)). Internal thinking differs from external action ${ }^{(3)}$.

\section{$※$}

(1) Article 19 is interpreted to protect freedom of silence. On this freedom, there are some cases in the Supreme Court of Japan. For example, in 512 ROUDOU HANREI 12 (1988), trade secrets in a company had been published in a bulletin of a political party, and then the company searched an employee who might have belonged to the party. The company asked the employee whether he belonged and ordered him to write a statement as to whether he belonged or not. The Supreme Court of Japan recognized the necessity and rationality of this search, but decided that the company could not ask the employee to what party he belonged if the company did not explain the relationship between the question and the trade secrets.

(2) Articles 39 and 40 of the Anti-Subversive Activities Law prohibit inciting a mob to set fire to houses in which someone lives. They should punish perceptible, objective actions, but not thoughts on which actions were based (44 (6) KEI - SHU 463 (1990)).

(3) Theories sometimes oppose each other. Article 19 of the Constitution protects conduct: Sasagawa Norikatsu, KenpouKougi 2 kihontekijinnken,79 (Yuhikaku, 1981)(Oosuga Akira edit.), Nishihara Hiroshi, Ryoushin No Jiyu 423 (Seibundo, 2001), Inoue Noriyuki, Gaibutekikoui to Shiso- Ryoushin no Jiyu, 610 Hougaku Seminar 84 (Nihon Hyouronn Sha, 2005). The protection extending no conducts: Hougakukyoukai edit. Tyukai Nihonkokukennpou Jyoukann (2) 399 (Yuhikaku, 1967), Miyazawa Toshoyoshi, • Ashibe Nobuyoshi rev. Zenntei Nihonnkokukennpou 235 (Nihon Hyoron Sha, 1978), Sato Isao, Kennpou (Jyo) Shinnpann 292(Yuhikaku, 1983), Hashimoto Kiminobu, Nihonnkokukennpou rev. 225(Yuhikaku, 1988). 
Therefore, Articles 12 and 13 provide that the rights of the Constitution are to be exercised unless we abuse them or they are exercised contrary to the common good. Because they are the Constitution's general provisions, every guarantee of the Constitution is to be understood according to them. For example, Article 20 provides freedom of religion, which guarantees that we can believe in gods or not, and if we believe in them, we are free to engage in religious activities. Nevertheless, in these two general provisions, we have limits that we are not to cross. But deciding which religious activities are permitted is difficult; generally, we cannot injure others even if our actions are based on our religious beliefs.

Again, we have absolute protection for our internal beliefs, but this never means the same protection for our external actions. So we have to decide which external actions are permitted, bearing in mind internal protection. Therefore, I introduce some cases of the Supreme Court of Japan that analyzed the relationship between thoughts and actions.

\section{Article 19}

Case 1: Defamation and a published apology (10 (7) MIN • SYU 785 (1956))

$\mathrm{X}$ (a candidate in a general election) announced that $\mathrm{Y}$ (a rival candidate) had engaged in corruption while he was vice-governor. Eventually, X lost a defamation case in which Y sued X, who was ordered by the District Court of Tokyo to pay damages and publish an apology. X paid damages, but did not publish an apology because X never had a mind to apologize to Y. Therefore, the Court's order to apologize to Y violated freedom of mind as guaranteed in Article 19. So, X appealed to the Supreme Court of Japan, but the Court denied the appeal.

The Court understood that publishing the apology was a duty for X, but a coerced apology would deny his human dignity, so he could not be directly forced to apologize. Next, the Court decided that a Court could order an apology be published in newspapers when its content was only to confess the facts of the case and to show regret for Y's trouble. Therefore, it never humiliated X, forced him to apologize against his will, or violated freedom of mind. Still, whether judicially forcing an apology was unconstitutional at all was never decided. On this point, Justices actively argued separate opinions.

Justice Kuriyama said that Article 19 protected only the religious mind, not thinking about ethics, especially an apology. So, if the Court ordered the apology, it did not violate Article 19. Certainly, this construction may be historically correct. Now, however, it is too restrictive because we have Article 20, which guarantees religious belief.

Justice Tanaka (Koutarou) said that Article 19 offered more protection, for example, for some general views of the world. But he agreed with the conclusion of the Court. He thought that it was desirable to apologize sincerely, but in fact we often apologize without sincerity. Nevertheless, such apologies hold some meaning for others. In other words, an apology has both moral and legal sides, and a Court could order a defendant to apologize legally even against his will.

In a dissenting opinion, however, Justice Irie criticized Justice Tanaka's opinion. Once an apology had been published, it was accepted as sincere. The published word "apology" or "apologize" would be taken as the defendant's intention. This completely violated his freedom of mind.

In his dissenting opinion, Justice Fujita said that the Court violated the defendant's freedom 
(silence) of mind because it ordered the apology against his will.

Obviously, Justices differed in their opinions, but they never thought it possible for the Court to go into the defendant's mind and change it. By the way, when we have injured others, we should naturally apologize and be responsible for damages even if it goes against our thinking. In defamation cases, we should apologize when we are first found to have injured someone's reputation through an action. We must responsibly compensate the injured party for that action. This is a problem of action, but not of mind.

Case 2: Rejecting the order to play the piano accompaniment to "Kimigayo" (61 (1) MIN • SYU 291(2007))

$\mathrm{X}$ was a public secondary school teacher in charge of music. She was ordered to play the piano accompaniment to "Kimigayo" (4), the national anthem, in an entrance ceremony, but refused to do so and received disciplinary action (a reprimand).

She said that "Kimigayo" was a symbol that had promoted Japanese invasion of Asian countries during the Second World War, in order to place the whole world under the Emperor, the Showa Tennou. Therefore, she could not let pupils sing "Kimigayo." If she was forced to play "Kimigayo," her freedom of mind would be violated. She asked to have the reprimand nullified (5).

The Supreme Court of Japan affirmed the reprimand, deciding there was no direct relationship between playing piano and her thoughts. Neither was it related to denial of her thoughts, which was that "Kimigayo" was harmful to her pupils' education. Even if she played "Kimigayo" in a ceremony, no one would necessarily believe that she positively and sincerely supported "Kimigayo." It was a matter of common knowledge that "Kimigayo" was sung in unison in the elementary school's entrance ceremony and that a music teacher was expected to accompany it. Therefore, it would be difficult for listeners to assume that her piano accompaniment itself expressed approval.

Certainly, if she disliked the song, but was forced to play it, she might believe it an infringement of freedom of mind (6). But she was a public employee, not a participant in the ceremony. Articles 99 and 73 of Constitutional Law provide that public employees are obliged to respect and protect the Constitution and to implement laws sincerely. Article 1 also provides that Tennou is the symbol of Japan and the Japanese people. And Article 32 of Local Official Law (Article 98, clause 1 of the National Public Service Law) provides that public employees shall obey their superiors' laws and orders. Public employees are in fact sworn to obey (Article 31 of Local Official Law and Article 97 of the National Public Service Law). The Law of the National Anthem and the Flag provides that

(4) Kimigayo generally means the religion of Tennou (the Japanese Emperor). The contents of the national anthem say that we Japanese hope the religion will continue forever. But most understand that "Kimi" is one's lover, and "Kimigayo" means that we and our lovers will long live together.

(5) Some scholars maintain that the remand should be nullified. See Nishihara, supra note (3) at 423, Sasaki Hiromiti, Jinnkennron Shiso-Ryoushin no Jiyu, Kokkaseishyo, 66 Seijyo Hougaku 1 (2001), Tonami Kouji, "Kimigayo" Piano Bannso Kyohi ni Taisuru Kaikokushobun wo Meguru Kennpou Jyo no Monndaitenn, 80 (3) Waseda Hougaku 105 (2005).

(6) Justice Fujita, in his dissenting opinion, argued that Article 19 protects a creed that prohibits forcing a person to act against her/his mind. 
"Kimigayo" is the national anthem. We have to be responsible for our actions of free will. She became a public employee by her free will, so not obeying these laws is selfish(7).

Case 3: The Tax Accountant Association as a compulsory participating corporation and its members' freedom of mind (50 (3) MIN • SYU 615 (1996))

To conduct business, a tax accountant has to become a member of the Tax Accountant Association (TAA). A local TAA group (the defendant) decided to contribute to a political party and then demanded that its members pay a special fee to cover the cost ${ }^{(8)}$. The plaintiff (a member of the TAA, the defendant) refused to pay because he could decide to which political party he contributed. He said that the defendant violated his freedom of mind if it forced him to pay the special fee against his will.

The Supreme Court decided that a member of the TAA had to obey its decision and pay the membership fee that laid the foundation of its economy. But the TAA was a corporation in which an accountant was forced to participate, and it had to consider its members' different thoughts. Thus, the TAA's demand that members pay a special fee against their political thoughts violated their freedom of mind.

Certainly, the defendant might enjoy freedom of mind as a corporation, support political thoughts, and disburse general membership fees to a political party. But the defendant was established according to law, and its legal purpose is to keep proper tax accounts, not to support a political party. Deciding whether the TAA could contribute to a political party to support a bill aiming to improve the tax accounting business is difficult. Is the bill's support against the legal purpose of the TAA? But even if political support is within the purpose, the TAA must consider thoughts of individual members forced to take part. Claiming specific payment from members to support a specific political thought violates others' freedom of mind.

\section{Article 20}

Case 1: Incantation to a mental patient based on religious belief (17 (4) KEI • SYU 302 (1963))

The accused was a priest of a Buddhist temple, consulted by a mother because her daughter's speech and behavior were strange. The accused decided that the daughter was possessed by an evil spirit (big raccoon dog) and performed an incantation to expel it. The accused closed the room and burned a lot of incense, filling the room with smoke to "smoke out the spirit." The daughter struggled desperately, but was held down and died. The accused was arrested on the charge of inflicting bodily injury resulting in death (Article 205 of the Criminal Code). The accused asserted

\footnotetext{
(7) Nonaka Toshihiko, Nakamura Mutuo, Takahashi Kazuyuki, Takami Katutoshi, Kennpou (1) 4th ed., 305 (Yuhikaku, 2006) understands that it is necessary for us to distinguish teachers and students in considering the problem of singing the national anthem.

(8) To be precise, the defendant contributed to a political organization of the local TAA, which contributed to the political party.
} 
that her incantation was religious conduct protected by the Constitution.

The Supreme Court rejected the assertion. She became guilty when she injured another's life or body even if her conduct was based on religious belief and she had acted in good faith.

Article 20 guarantees freedom of religion that includes both one's internal belief and conduct coming from it. But the Constitution also provides Articles 12 and 13, general provisions that must be considered in understanding the meaning and extent of fundamental rights provided in the law. These articles provide that human rights guaranteed in the Constitution should enjoy maximum, but not unlimited respect. We always have to exercise them in conformity with the common good, never abusing them. Accordingly, we can enjoy religious conduct, but we cannot abuse the right. What "abuse of right" means is not very clear, but conduct that injures another's body or life is.

Case 2: Dissolving the Religious Corporation Oumu Shinnrikyo ((50 (1) MIN • SYU 199 (1996))

Oumu Shinnrikyo was a religious corporation, but its guru manufactured poison gas to kill people and tried to take over Japan. The Tokyo District Court ordered the corporation dissolved under the Religious Corporation Code. Nevertheless, the corporation did not obey the order because it violated freedom of religion of the corporation and its members.

The Supreme Court asserted that the Code regulated secular, but not religious and spiritual conduct. As a result, the law should prohibit conduct markedly detrimental to the public interest or deviating from its purpose, not religious thinking. Certainly, the Court said, the order to dissolve could disturb the religious conduct of the corporation's members because it disposed of the corporation's assets used to conduct religious acts, especially houses, both to live in and to perform religious ceremonies. And the order should not affect their religion.

But the Court decided that the order would deprive the corporation only of its corporate status, not prohibit members from meeting and conducting religious activities. Of course, we must have the highest regard for religious activities, but they are not protected absolutely; they have limits. Even if the order was against their interests, those disadvantages were indirect and de facto to their religion. The order was a necessary and unavoidable choice for dealing with Oumu Shinnrikyou's conduct.

The Court emphasized that the order never prohibited religious belief or intruded upon the corporation's members internally, but regulated conduct detrimental to the common good. The order's disadvantage to religious conduct was indirect or incidental and thus insignificant. The religious conduct behind the corporate status was clearly detrimental to the common good and had to be regulated. Therefore, the order was necessary and essential regulation of religious conduct and did not violate freedom of religion as guaranteed by Article 20. While most scholars support this decision, some think the decision is too soft and members should be prohibited from meeting each other. 
Case 3: Absent from class on fathers' visiting day, according to one's religious belief (37 (3) GYO • SYU 347 (1986))

God orders believers to do and not to do certain things. Even if it is easy for an ordinary man to perform a certain duty, it is not easy for a believer to perform it when his God prohibits it. Is it a violation of his religious mind when he is forced to do something against his religion? Can he always be exempted from obligations that others must perform, when his God orders otherwise?

To show how children took part in class, a secondary school in Tokyo asked fathers to visit on a Sunday. The visitation had to be offered on a Sunday because most fathers were company employees and could not participate except on Sunday.

On the Sunday, a Christian pupil was absent from the class for visiting fathers because he went to church. His father, a minister, insisted that the school should consider his son present. Going to church every Sunday was a religious action, so it was a dilemma for the pupil to decide whether to attend class against God's order or to attend church as God ordered.

The District Court of Tokyo did not accept the father's insistence that the school consider the son present. After comparison of advantages and disadvantages, the Court decided that fathers could recognize how their children studied in classes during the morning and consult with teachers in the afternoon discussion meeting. The fathers' opportunity to take part in the class and observe their children's behavior was very beneficial, whereas for the son to be marked absent one day was relatively insignificant. The day's purpose was to keep a record for informing the next year's teacher of the pupils' status, but missing that day would never affect later school admissions or employment.

Conduct based on religious belief sometimes conflicts with secular obligations. Such events are dilemmas for believers-whether to obey their religion or obtain a secular interest. We should respect their position as much as possible, especially when secular disadvantages suffered by faithful believers are insignificant. In the next case, a student was expelled from a higher technical college, thus causing him significant damage.

Case 4: Refusal to participate in the Kendo actual skills class (50 (3) MIN • SYU 469 (1996))

In a higher technical college, health and physical education (HPE) was a required subject, including the Kendo lessons. The plaintiff was a student in the school and a believer of Jehovah's Witness that insists on absolute pacifism. Believers are prohibited from using force, especially taking part in a martial arts class. The student explained his circumstances and requested alternatives, for example, submitting reports. But the school did not grant his request.

Nevertheless, in his kendo class, he participated only in lecture and warming-up, but never took part in actual practice, during which time he knelt in the formal Seiza position, took notes of practices, and submitted reports to the teacher, but in vain. Despite his efforts, he was refused the required HPE credit and was not promoted. The next year, the same happened, and then he was expelled. The school decided he had no likelihood of completing the course, which was based on school rules. He sued for denial of the disciplinary action.

The Supreme Court of Japan accepted his allegation and cancelled the action. The Court 
recognized that the school violated the "extraneous consideration" rule, which meant that when the school disciplined a student, it had to consider only facts inherent to the case, not those outside of it. First, the disciplinary action was based on school rules providing, "when a student will not complete the school course because of poor performance, he may be compelled from the school." However, the student was a top performer in his class, notwithstanding a grade of F in HPE. Second, he refused kendo practice because of his religion, freedom of which is guaranteed in the Constitution. Thus, he should not suffer disadvantages when he practices his faith. Third, the Kendo lesson is not significant to the school's purpose, which is to train immediate manufacturers, not athletes for kendo. Nevertheless, the school insisted he practice kendo and expelled him despite high grades except for the Kendo class. The Supreme Court decided that because the school had abused its authority in disciplining a student, the expulsion was repealed.

In this case, the school insisted that the student freely selected the school, notwithstanding he recognized HPE as a required subject, including the Kendo practice. And the school did not offer compulsory education. The school said that it was only fair for him to follow school policy. But this case happened in his expulsion, not in the entrance examination. The disadvantage from school expulsion would be very severe, following him for life. And it would have been easy for the school to think of an alternative, for example, running, doing push-ups, and so on. In addition, the Ministry of Education, Sports, Science and Technology (MEXT) notified that physical education credits should be obtained as students are able.

\section{Conclusion}

Our thoughts are guaranteed absolutely when they are kept inside, but have a close relationship with conduct based on them. Can we not regulate behaviors that emanate from our thoughts? Otherwise, all conduct may be permitted. Thoughts are protected absolutely only when they are kept within our minds. Actions can be regulated when they violate another's right(s) and are detrimental to the general interest.

Religion has two sides, internal belief in God and practice of God's orders. The former is guaranteed absolutely in the Constitution, but the latter is not because it can impact others or society, so it may not be practiced freely at all. That is correct under the general provisions of Articles 12 and 13 that prohibit abuse of rights and demand that we exercise rights within the common good. Accordingly, a person must be responsible for her/his conduct if s/he hurts someone bodily and is detrimental to the common good-even if asserting that God has ordered the action.

But how should we decide when God orders believers not to do something? How can we decide if believers face a dilemma if they obey God's orders or obtain a secular interest? Case law suggests that we ought to decide after comparison of advantages and disadvantages. 